\title{
Japan's protected wetlands grow under NGO pressure
}

Tokyo. The Japanese government won qualified praise after hosting the world's leading forum for the preservation of wetlands and waterfowl, but on past performance the good intentions of Japan's environmentalists may be overwhelmed by the pressure for development.

The occasion was the fifth meeting of the Ramsar wetlands convention, the treaty drawn up in 1971 at the Iranian city of Ramsar, and now ratified by 77 governments. This year's meeting was at Kushiro, on Japan's northern island of Hokkaido, from 9 to 16 June.

In a move unfamiliar in this country, Japan's fledgling non-governmental organizations (NGOs), such as the Japanese branches of the World Wide Fund for Nature (WWF) and Friends of the Earth, banded together before the conference to push for better protection of Japan's own rapidly disappearing wetlands.

Tidal flats around Japan are important resting and feeding points for migratory birds and are also a vital resource for fisheries. It is reckoned that, during the long postwar economic boom, more than half of Japan's natural coastline on the four main islands disappeared under concrete walls, sea defences and land reclamation projects. The trend continues: the government's Environment Agency let slip during the Kushiro meeting that, between 1979 and 1985, Japan lost another 4,000 hectares (or more than 7 per cent) of its remaining tidal flats.

Before the Kushiro meeting, only four wetland sites in Japan, totalling 10,000 hectares, were listed for protection under Ramsar. No rich nation has fewer. Worldwide, more than 600 sites covering more than 38 million hectares have been designated by the 77 members of Ramsar. Britain, for example, has nominated 60 sites covering more than 270,000 hectares. And none of the Japanese sites is on the coast.

The NGO coalition at Kushiro pushed the Japanese government hard to list more sites, particularly tidal flats. It had in mind such sites as the Wajiro tidal flat in Hakata Bay, on the southern island of Kyushu, where the local government plans to build an artificial island in the middle of the bay, and Fujimae tidal flat near Nagoya, which may be used as a garbage dump. Although it failed to get any tidal flats listed, the Japanese government did add five more inland sites (the largest being Lake Biwa near Kyoto) totalling more than 70,000 hectares to the Ramsar list.

One of the aims of the conference was to draw up guidelines for the "wise use" of wetlands. A draft presented at the meeting called for mandatory environmental impact assessments of proposals for development projects at Ramsar sites. But Japan, which has no legally binding system of environmental impact assessment, balked. Instead, it insisted that the guidelines should "endorse", but not "require", assessments.

Such impact assessments as there are in Japan are usually carried out by the organizations responsible for development projects, and almost invariably favour development. Ramsar delegates and NGOs are particularly concerned about plans by Japan's Construction Ministry and the Hokkaido Development Agency to build a huge flood control channel in the watershed of the

\section{New boss for Russian research foundation}

Moscow. To much surprise, Andrei Gonchar, vice-president of the Russian Academy of Sciences (RAS), is not to be the chairman of the Russian Foundation of Basic Research, the Russian government's new instrument for making grants to researchers.

Although Gonchar was named last year as director-organizer of the foundation (RFBR), a decree now signed by President Boris Yeltsin says that the job will instead go to 46-year-old Vladimir Fortov, a research director at the RAS Institute of High Temperature Physics.

Although Gonchar has been considered the most likely chairman, his official appointment has been repeatedly postponed for the past six months. The explanation is that Gonchar has refused to give up being vice-president of the RAS. The charter of RFBR expressly prohibits its chairman from occupying any other leading position at the academy. The government and the Ministry of Science are also determined to keep the foundation and academy separate.

Andrei Gonchar has repeatedly said that he cannot resign as RAS vice-president because that is an elected position, and that if he had to choose between the academy and the foundation, he would remain at the academy. But, judging from the negative reaction of the academy leadership to the appointment of Fortov, Gonchar never seriously considered that one line in the charter would disqualify him as chairman of the foundation. Indeed, in December 1992, he insisted to the press that the RFBR Charter does not mention the possible conflict of interest, suggesting that Gonchar had not read this document, then published for all to read.

But Yeltsin's failure to appoint Gonchar does not reflect disapproval of his work as the leader of RFBR during its first year. First Deputy Minister of Science Andrei
Bibi river, which flows into Lake Utonai in Hokkaido; one of Japan's Ramsar sites. They fear it could alter water levels. Under the gaze of the media at Kushiro, Japanese government officials promised that there will be a proper environmental impact assessment of this project.

Ramsar governments also agreed to double the convention's annual budget to US\$1.5 million for the next three years. The Japanese NGO contingent is particularly happy that Japan's Environment Agency has agreed to form a committee of experts, including NGOs, to advise on protection of wetlands.

It remains to be seen if the Japanese government will live up to its promises to protect its own Ramsar sites. The Environment Agency seems determined to do so, but the little agency, with little political power and a tiny budget, is often overruled by more powerful ministries with other interests.

David Swinbanks

Fonotov rates Gonchar's achievements highly. Chiefly, he made the RFBR the first really functioning research foundation in Russia.

The foundations's first grants were of unquestionable value to Russian science. One of the foundation's experts, Konstantin Kikoin of the Kurchatov Institute, says that Gonchar was able (at least in the field of physics) to gather a qualified team of experts, and did everything possible in order to ensure that grants were awarded to the very best. At the RAS Institute of Physics, the St Petersburg Physical Technical Institute, Nizhny Novgorod (formerly Gorkii), Kazan, and many other provincial scientific centres in Russia, Kikoin says that "science woke up."

But the foundation's activities have also been the cause of some criticism. Gonchar was at best tactless when he awarded grants to practically all members of the praesidium of the RAS, as well as to all the foundation's own appointed experts.

The main criticism is that the foundation mainly concerned itself with work performed within the framework of the RAS. Andrei Fonotov says that, according to his data, 85 per cent of the grants went to academy laboratories, where most of the foundation's experts also work. Perhaps a half of Russia's basic research has thus been outside the foundation's gambit.

Resentment of this emphasis on the academy's own scientists has been expressed by such non-academic institutes and associations as the St Petersburg Union of Scientists, the Russian Physical Society and the Russian Astronomical Society. The initiative to replace Gonchar was eventually taken by Boris Saltykov, the minister of science. Vladimir Fortov was chosen after lengthy discussions.

Vladimir Pokrovsky 